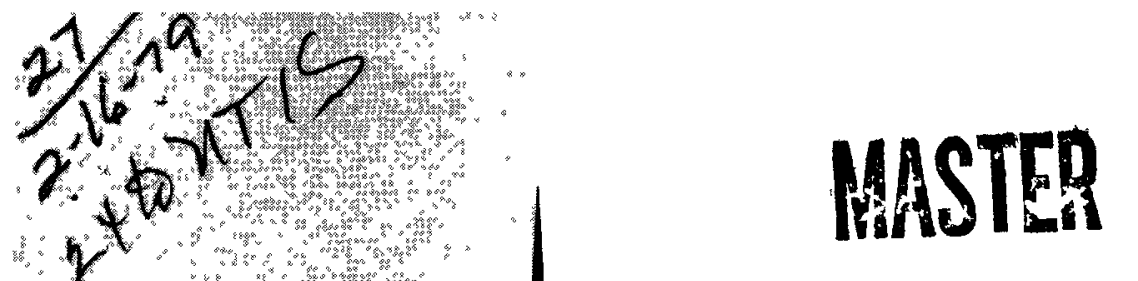

Dist. Category uc. 45

\title{
Recycle Process for tatB PBX Parts
}

\author{
A. Gordon Osborn \\ Thomas L. Stallings \\ Herbert D. Johnson \\ DEVELOPMENT DIVISION
}

DECEMBER 1978

Process Development 


\section{NOTICE}

This report was prepared as an account of work sponsored by the United States Government. Neither the United States nor the United States Department of Energy, nor their employees, nor any of their contractors, subcontractors, or their employees, makes any warrany, express or implied, or assumes any lega 1 liability or responsibility for the accuracy, completeness or usefulness of any information, apparatus, product or process disclosed, or represents that its use would not infringe privately-owned rights.

Printed in the United States of America

Available from

National Technical Information Service

U. S. Department of Commerce

5285 Port Royal Road

Springfield, VA 22161

Price: Printed Copy $\$ 4,0 c$; Microfiche $\$ 3.00$ 


\section{DISCLAIMER}

This report was prepared as an account of work sponsored by an agency of the United States Government. Neither the United States Government nor any agency Thereof, nor any of their employees, makes any warranty, express or implied, or assumes any legal liability or responsibility for the accuracy, completeness, or usefulness of any information, apparatus, product, or process disclosed, or represents that its use would not infringe privately owned rights. Reference herein to any specific commercial product, process, or service by trade name, trademark, manufacturer, or otherwise does not necessarily constitute or imply its endorsement, recommendation, or favoring by the United States Government or any agency thereof. The views and opinions of authors expressed herein do not necessarily state or reflect those of the United States Government or any agency thereof. 


\section{DISCLAIMER}

Portions of this document may be illegible in electronic image products. Images are produced from the best available original document. 


\title{
RECYCLE PROCESS FOR TATB PBX PARTS
}

\author{
A. Gordon Osborn \\ Thomas L. Stallings \\ Herbert D. Johnson \\ DEVELOPMENT DIVISION \\ (December 1978) \\ Process Development
}

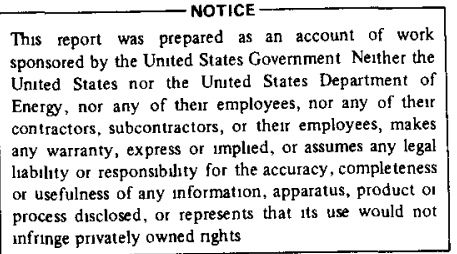

This report was prepared as an account of work United States nor the Unuted States Department of Energy, nor any of therr employees, nor any of therr contractors, subcontractors, orples or assumes any legal infringe privately owned rights

\begin{abstract}
A process was developed for recycling scrap TATB PBX parts into reusable PBX. Pressed densities of two lots of RX-03-BB formulated from scrap parts were found to be slightly above normal and physical strengths were adequate.
\end{abstract}

\section{INTRODUCTION}

TATB PBX scrap is generated in two forms, flakes from fine semigranular machine cuttings, and solid parts. The solid parts are pretested physical property specimens, unused machining parts or reject pressings. During production the estimated reclaimable material will be $50 \%$ machine cuttings, and $50 \%$ in the form of pressed pieces. Previous development work on recycling TATB PBX scrap has involved only machine cuttings. This form of scrap is more easily recycled since the small flakes lend themselves to immediate reprocessing without additional grinding or dissolving steps which are required with larger solid pieces.

A method was developed to recover the larger solid scrap parts by dissolving the parts in a solvent. Only the Kel-F is dissolved, while the insoluable TATB particles remain in the slurry. Thus, in a single step, solid parts can be reduced to a form suitable for immediate regranulation. Two lots of $\mathrm{RX}-03-\mathrm{BB}$ were regranulated from dissolved parts.
For one lot a modification of the Pantex procedure was used in the 30litre reactor, while for the other larger lot, a modification of the Holston processing method was used in the 300-gallon kettle. The rate of solution of the scrap parts, the particle size distribution of the reclaimed TATB and physical properties of the reclaimed material were measured. These results are presented in Table $I$ and Figs. 1, 2 and 3. Also, included for comparison are data from recycled machining scrap, a lot of $\mathrm{RX}-03-\mathrm{BB}$ regranulated from machine cuttings, No. 7027-145-01(1), and average physical properties of eight standard lots of $\mathrm{RX}-03-\mathrm{BB}(2)$, made from virgin TATB.

(1) A. Gordon Osborn, Thomas L. StaZlings and Herbert $D$. Johnson, Recycling TATB PBX, MHSMP-78-3 (February 1978).

(2) A. Gordon Osborn, Thomas $L$. Stallings and Herbert D. Johnson, TATB PBX Development (Particle Size), MHSMP-77-18D (March 1977). 
Table I. Reclaimed TATB PBX Physical Properties

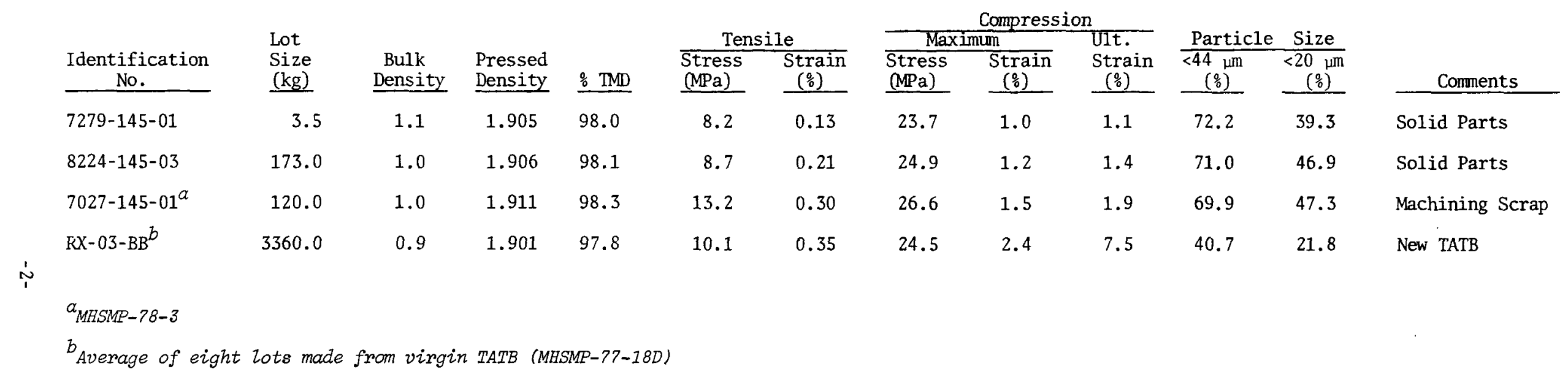




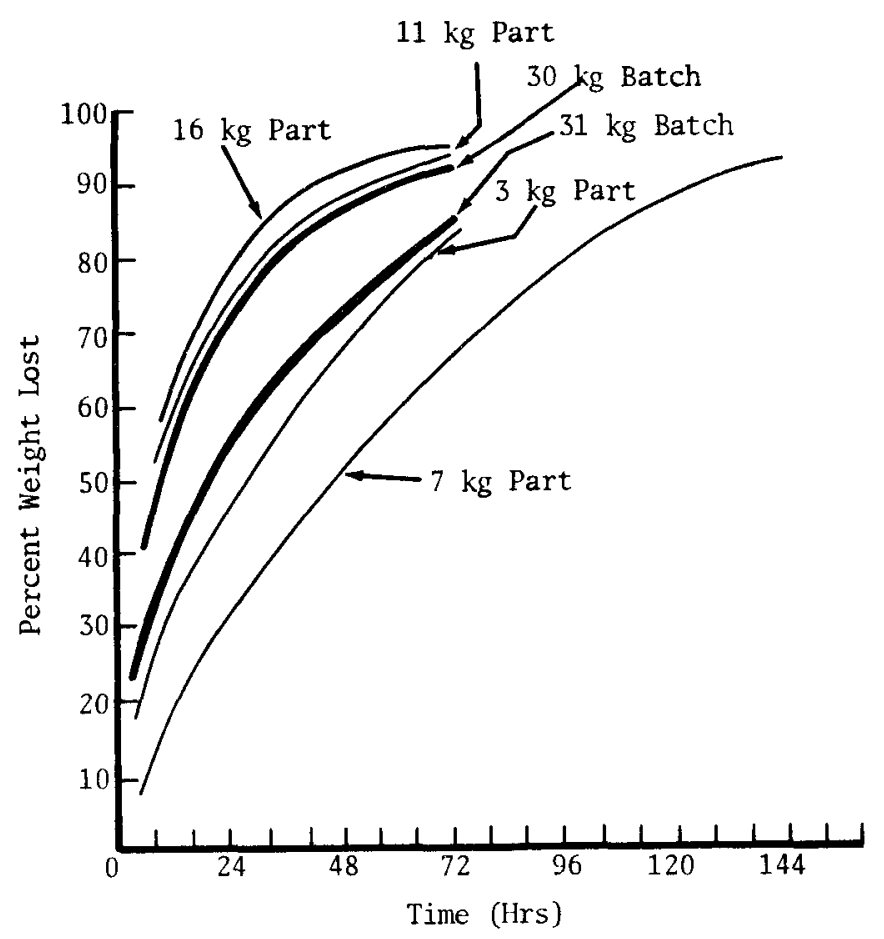

Fig. 1. Dissolving Rate (Economy Mi11)

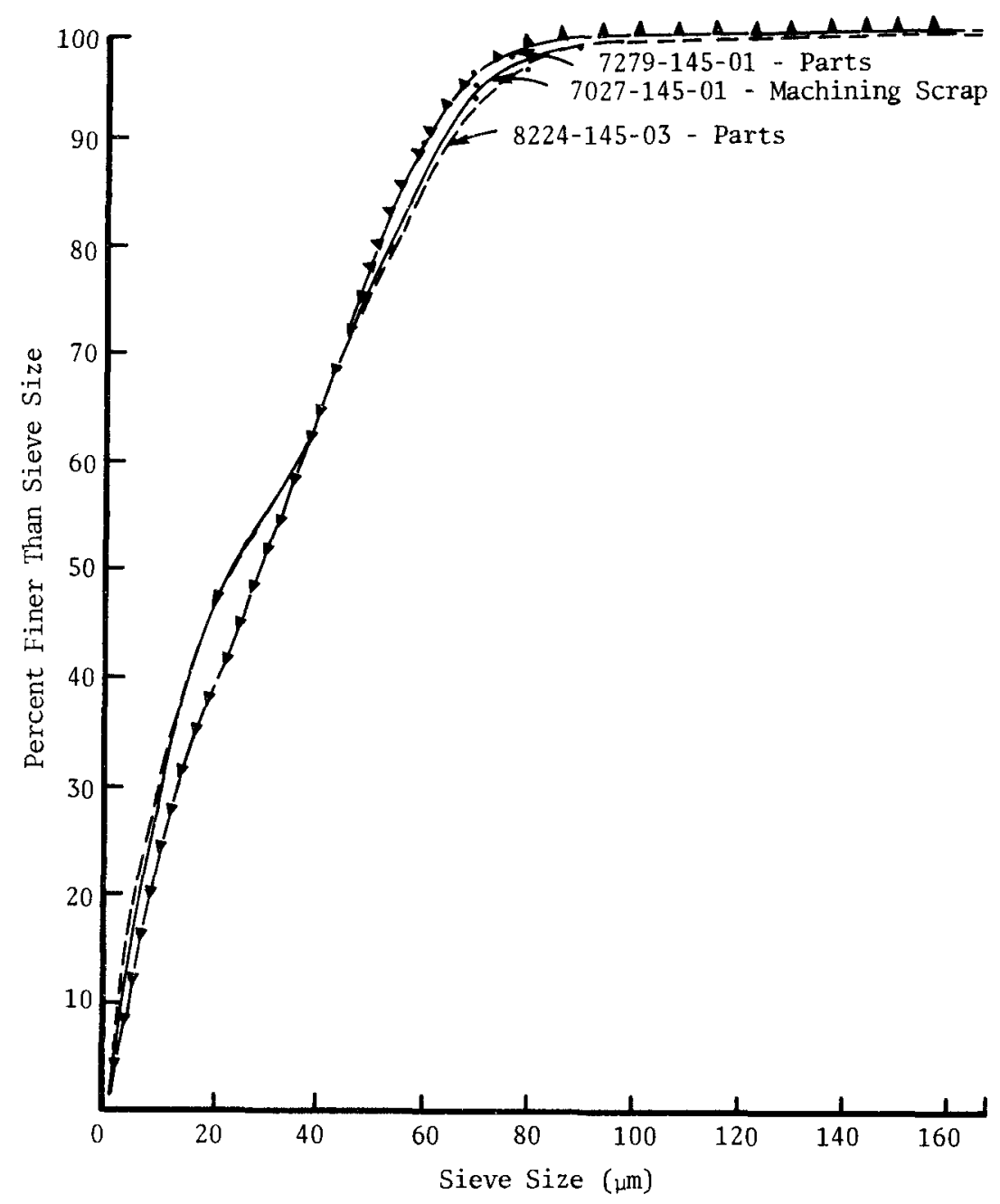

Fig. 2. Cumulative Distribution Reclaimed TATB 

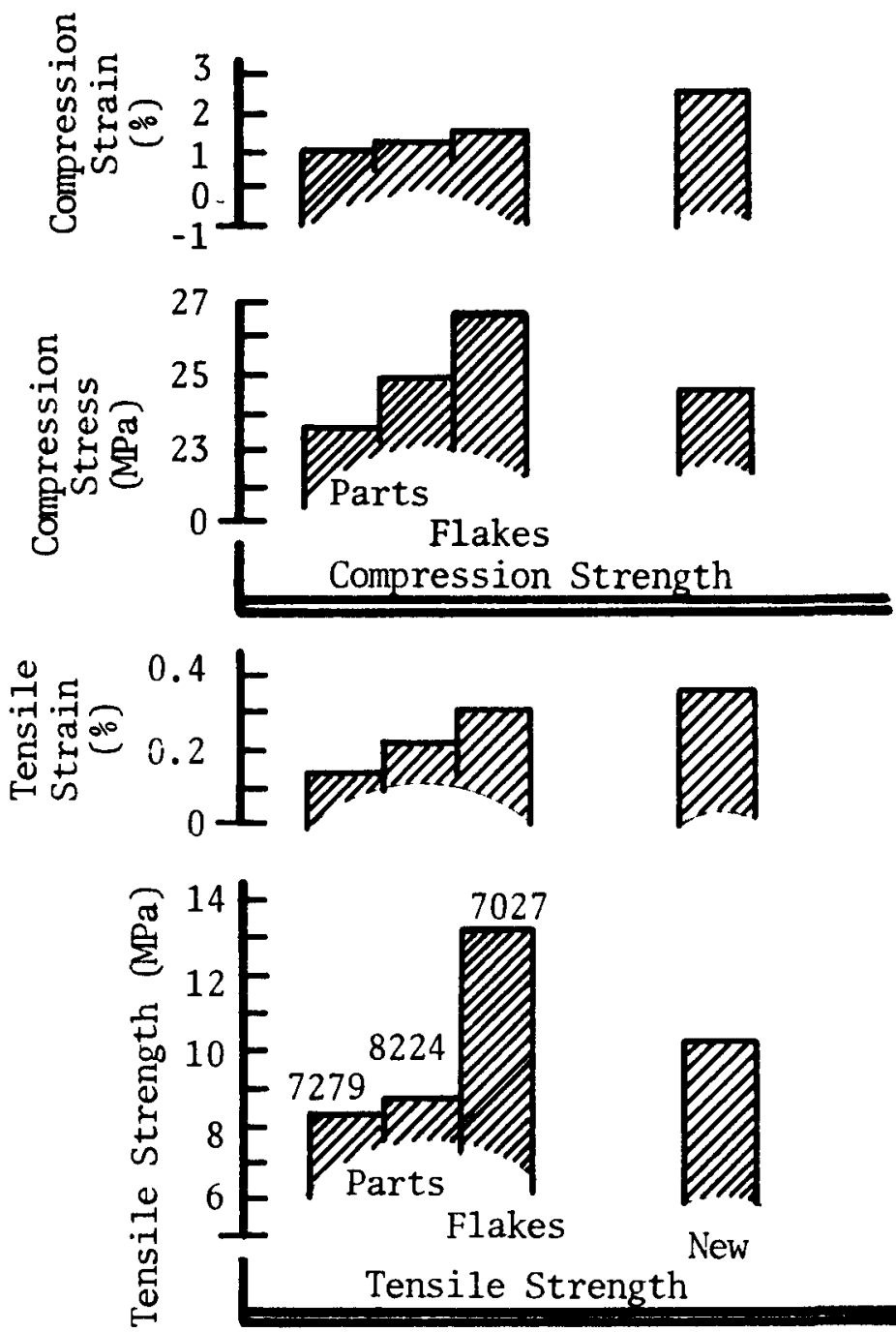

Fig. 3. Evaluation of Reclaimed RX-03-BB 


\section{SOLUTION OF SCRAP PARTS}

The scrap parts were dissolved in an Economy Pebble Mill. The mill was modified by removing the ceramic balls and adding solvent. The rotating motion of the mill continuously abraded and dissolved the TATB parts. Approximately 19 litres ( 5 gallons) of ethy 1 acetate was mixed with approximately $32 \mathrm{~kg}$ (70 pounds) of TATB scrap. Mil1 rotation was continuous at $20 \mathrm{rpm}$. The mill size is $0.53 \mathrm{~m}$ in diameter by $0.71 \mathrm{~m}$ long with a sealed side opening of $0.19 \mathrm{~m}$ by $0.29 \mathrm{~m}$. Fig. 1 shows the approximate solution rate for various size pieces including two batches of miscellaneous parts. These results were obtained by stopping the mill daily to estimate the weight of the parts remaining undissolved. As shown in Fig. 1, there is wide variation in the rates of solution. Genera1ly, between 55 and $75 \%$ of a given batch of material is dissolved in a 24-hour period.

\section{REGRANULATION-PANTEX PROCEDURE}

Scrap dissolved in the Economy Mill was regranulated into a small lot of $\mathrm{RX}-03-\mathrm{BB}$ using a modification of the standard Pantex procedure. The RX-03$\mathrm{BB}$ was first dissolved in ethyl acetate in the mill, regranulated in the 100gallon kettle and dried to remove the ethyl acetate. A small $3.5 \mathrm{~kg}$ batch (No. 7279-145-01) was granulated by the Pantex process in the 30-1itre reactor to yield material for pressing and testing. This slurry procedure employes a $133 \mathrm{~g} /$ litre RX-03-BB/water ratio, using an MIBK and NBA solvent system and applying heat and an air sweep to remove the solvent and form the granules.

\section{REGRANULATION-HOLSTON PROCEDURE}

Lot No. $8224-145-03$ is a $173 \mathrm{~kg}$ blend of two batches regranulated in the 300gallon kettle by the Holston processing method. The Holston and Pantex process- ing methods for making TATB PBX differ as to solvent system and method to achieve granulation. The solvent used by Holston is ethyl acetate, which has a relatively high water solubility. A slurry is formed at a low water level with the TATB and the lacquer, then the granules are formed by adding sufficient water to extract the solvent thus causing granule formation. The solvent is then stripped by distillation. Scrap $\mathrm{RX}-03-\mathrm{BB}$ dissolved in ethy 1 acetate in the mill is thus suitable for inmediate reprocessing by the Holston method. Incorporated into both the Pantex and Holston procedures is a clean-up step. All recycled material, after solution in a solvent and before regranulation, is strained through a grid to remove foreign inclusions which may have inadvertently become incorporated into the material.

\section{PARTICLE SIZE}

The TATB particle size data obtained from the two lots regranulated from solid parts are shown in Fig. 2. Also included are results of a lot reported previously(1), which was regranulated from machine cuttings. As shown from the cumulative distribution plot, there is very little difference in the particle size distribution from TATB extracted from scrap parts or machine cuttings. However, the recycling processes for both types of material reduce the TATB particle size considerably compared to virgin TATB.

\section{PRESSABILITY}

As shown in Table I, pressed densities are well within the normally expected range for pressings used for physical properties specimens. Though the reclaimed material may have densities slightly higher than normal RX-03-BB, the density variations are minimal and do not reveal differences that may be attributed to the use of recycled $\mathrm{RX}-03-\mathrm{BB}$ or differences in TATB particle size distribution. 


\section{PHYSICAL STRENGTH}

Tensile and compression strengths of the four lots of RX-03-BB listed in Table I are graphically displayed in Fig. 3. Both tensile and compression stress and strain levels exhibit the same trends. The small lot made in the 30-1itre reactor has lower stress and strain than the larger lot made by the Holston procedure. Of the recycled group in Fig. 3, the lot made from machine cuttings or flakes has the highest values. However, the physical strengths of all of the recycled lots are adequate.

\section{CONCLUSIONS}

The feasibility of recycling and recovering TATB PBX has been successfully demonstrated. Scrap parts can be dissolved, regranulated and yield adequate physical properties. Also, the feasibility of recycling flakes produced by machining has been demonstrated and previously reported(1).

The recovery of solid parts posed more of a problem than the machine cuttings or flakes since the size of solid parts must be reduced. Dissolving was chosen over grinding for size reduction. A very strong grinder would be required since $\mathrm{RX}-03-\mathrm{BB}$ is a very tough material. Also additional machining would be required to saw parts to a size which would fit into the jaws of a grinder. The ground parts would ultimately be dissolved in a solvent and then regranulated.

By using a dissolving chamber, scrap parts are placed directly in a solvent chamber and prepared for regranulation in a single step, with very little labor involved. The only limit to the size of a part or the quantity of material dissolved is the size of the solution vessel and the opening into the vessel. 
DOE

Ralph E. Caudle

Assistant Director of Operations

Military Application

Attn: Robert E. Clough

Washington, DC

$\underline{A L O}$

H. N. Meyer, Director

Weapons Development Division

R. R. Fredlund, Jr., Director

Classification \& Technical Information

$\underline{\text { AAO }}$

P. M. Ramey, Chief, Operations Branch

Mound Facility

R. T. Braun

$\underline{\text { SLL }}$

R. D. Cozine - Org. 8180

$\underline{L L L}$

G. L. Dittman (10 Copies)

Attn: A. C. Van Dyk

C. T. Brockett

Technical Information Dept.

LASL

E. H. Eyster - WX-DO

Attn: J. J. Wechsler

R. N. Rogers - WX-2

J. Aragon - WX-3

Report Library - ISD-4
SLA

B. E. Arthur - Org. 1570

J. C. Crawford - Org. 2500/

D. H. Anderson - Org. 2510

J. C. King - Org. 2300/

C. B. McCampbell - Org. 2310

Central Technical Files - Org. 3141

TIC

Technical Information Center (27 Copies)

Oak Ridge, TN

$\underline{\mathrm{UK}}$

Jack Kirkham

Atomic Weapons Research Establishment

Aldermaston, Reading, England

$\underline{\mathrm{PX}}$

Division Manager, Mfg. Engineering

Division Manager, Quality

Division Manager, Development

Division Manager, Manufacturing

Division Manager, Safety \& Fire Protection

Education \& Training Center (5 Copies)

Technical Library (5 Copies)

Circulation Copy:

(1) Asst. Plant Manager

(2) Plant Manager

(3) Mq̧H-SM Co., Inc., Lexington, $\mathrm{KY}$ 